\title{
BEYOND TEACHING ENGLISH: EFL STUDENTS' ACCOUNTS OF LEARNING OUTCOMES IN A COOPERATIVE CLASS
}

\author{
Jelena V. Grubor \\ State University of Novi Pazar, Department of Philology Sciences
}

Since student learning outcomes (SLOs) have assumed the central role in presentday teaching, and cooperative learning has been shown to bring many benefits to students, our main aim is to explore how students perceive SLOs in order to determine their key dimensions. The sample included 24 third-year female students attending a philological course. The participants' evaluation of the acquired knowledge/skills and their implementation was explored via content analysis. The results show that SLOs include: (1) knowledge, (2) capabilities, and (3) applicationof-the-acquired dimension (prompted by volition and affect). The main conclusion is that the participants appear to view learning English not as a primary means to learn the language per se, but as a means to learn different subject content through English. Other variables may have additionally contributed to such results: L2 as the language of instruction and positive attitudes to the learning environment.

Keywords: cooperative learning (CL), English as a foreign language (EFL), student learning outcomes (SLOs).

\section{INTRODUCTION}

Learner responsibility and independence are increasingly being placed at the forefront of contemporary teaching methods and approaches, as well as practices of any school subject nowadays. One of the main preconditions for such an outcome to be achieved is that learners become aware of not only what they have learnt, but also what they are able to do with their newly acquired knowledge/skills.

Learning outcomes (LOs), therefore, have become the central part of modern classrooms, as well as a reliable means of assessing student knowledge and skills. They are to do with teacher or learner statements, i.e. learning outcomes and student learning outcomes respectively. In specific, they state: (1) what students will acquire/learn (knowledge), (2) what they will be able to do (skills), and (3) what they will be able to demonstrate (functional use) within a set period (e.g. by the end of a lesson/unit, term, school year, primary school etc). Accordingly, student learning outcomes (SLOs) typically include the cognitive element since they pertain to knowledge (what students would learn), student capabilities because they relate to what students would be able to do (abilities, skills, competencies), and affective, i.e. positive attitudes and opinions that students would form along the process, as well as 
their resolve to achieve favourable outcomes. As regards assessment, Purpura and Turner (2014) proposed Learning Oriented Assessment (LOA), which 'acknowledges the centrality of learners, learning processes, and learning outcomes (...) in the educational context' (p. 11). The central point of LOA is 'on learning tasks, self- and peer-evaluation, and effective scaffolding and feedback' (Jones, \& Saville, 2014, 2016).

In a similar vein, cooperative learning is a teaching approach that views learner as a proactive agent of the learning process, i.e. the one 'accountable for their own learning and learning of others' (Olsen, \& Kagan, 1992: 8). Cooperation thus entails 'working together to accomplish shared goals' (Johnson, \& Johnson, 2014, p. 481), with the ultimate aim to maximise the learning of each group member (ibid.). The mere concept of cooperation, however, underpins many theories. Constructivists, for instance, emphasise autonomy and cooperation of students as an integral part of the learning process (Wolff, 2007). The theory of cognitive development stipulates that cooperation is necessary for the cognitive development in that that learners mentally rehearse and reconstruct information in order to store them in memory and incorporate them into the existent cognitive structures (Johnson et al., 1998; O'Donnell, 2006), through interaction with their peers and/or parents/instructors. However, the central theory that forms the core of the cooperative learning approach is social interdependence theory, whereby interdependence can be regarded as positive (cooperation: working with others), negative (competition: working against others), and 'neutral' (individualistic goal structures: working for oneself, without wanting to help or hinder other people's success). The nature of social interdependence, i.e. its structure determines the format of interaction and consequently affects outcomes (Johnson, \& Johnson, 1974). Accordingly, cooperation among group members is desirable (being positive), and thus crucial for favourable class outcomes (Grubor, 2014). ${ }^{1}$ When it comes to assessment in a cooperative class, students' efforts are evaluated on a criteria- and not normreferenced basis, as it is the case with competitive learning (Johnson, \& Johnson, 2014). This brings us to the following conclusions: the employment of this approach is fairer to students, and crucially, classes are learner-centred and assessment learning-oriented. ${ }^{2}$

Although this approach can be used in any subject at any level of education (Johnson et al., 2007), the focus of our paper will be on its use in English language classrooms (i.e. within the context of learning English as a foreign language, L2). In line with it, in contrast to all other teaching methods and approaches currently employed in English teaching, cooperative learning (CL) has been extensively researched. Due to limitations of space, we will just briefly introduce some of the main findings concerning its employment.

Namely, many studies have provided support for the implementation of this approach in class for a number of reasons. CL is effective in promoting academic achievement with students of all ages (Hornby, 2009). Many studies have shown that CL results in better achievement of students (Fathi-Ashtiani et al., 2007; HertzLazarowitz, \& Miller, 1992; Johnson, \& Johnson, 1989; Slavin, 1995; Watson, 1991). It also creates a positive learning environment (Brecke, \& Jensen, 2007; 
Zhang, 2010; Duxbury, \& Ling, 2010), enhances peer relationships and higher academic achievement in younger adolescents (Pritchard, \& Woollard, 2010; Roseth et al., 2008; van Wyk, 2012). It is further beneficial to high-achievers when grouped homogeneously, and to average- and low-achievers despite the grouping format (Baer, 2003). Moreover, the cooperative approach encourages critical thinking (Cohen, 1994; Brandon, \& Hollingshead, 1999; Johnson, \& Johnson, 2014), social skill development (Marr, 1997; Slavin, 1995; Tarim, 2009), life skills (Grubor, 2014), personality development (Brecke, \& Jensen, 2007; Huber, 2004; Zhang, 2010) etc. Finally, students are taught to be active (Cohen, 1994) and proactive (Grubor, 2014) in the way that they are prepared to adopt their role of a future responsible citizen, which is particularly relevant to the subject matter of the current study.

In addition, this approach prompts students to constantly connect class/subject matter content and their general knowledge. ${ }^{3}$ This is closely connected to the view of language that this approach takes, i.e. primarily interactional. According to Richards and Rogers (2015, p. 24), interactional view of language regards language as 'a tool for the creation and maintenance of social relations', which is typically the crucial function of any communication. In other words, the focus is not so much on the product, but rather on the process how to arrive at some destination (e.g. desirable outcomes, through successful completion of a task), and the social function. Namely, students taught via this approach are trained to be independent, responsible for the learning process, aware of their actions and consequences arising from them. This brings us to the fact that theoretically such students should regard English (in this concrete context) as a vehicle that enables or will enable them to acquire certain in-class and/or out-of-class subject matter content, and, more importantly, to put them into practice effectively.

Since the focus of the majority of studies has been to explore the link between $\mathrm{CL}$ and learner (academic) achievement, ${ }^{4}$ our goal is to explore the link between the employment of CL and student perceptions of their LOs. In specific, the present study is a follow-up to our previous research, where we presented statistical data in relation to the topic at issue (Grubor, 2014). ${ }^{5}$ The main aim of the initial study was to determine whether there were differences in self-reported evaluation of learning outcomes between the cooperative and non-cooperative groups (defined as such according to the criterion whether the English teacher predominantly employed CL). Herein, however, we aim at focusing on the 'cooperative group' solely and exploring the content of students' extra-language accounts of learning outcomes in order to gain a deeper insight into their self-reported evaluation of SLOs.

\section{Methodology}

The study was conducted in a philological class upon the completion of the unit entitled 'Earth: SOS' (textbook: Enterprise 4), which deals with the issues of environmental disasters and accidents. As stated earlier, in the initial study (Grubor, 2014), we quantitatively compared self-reports on learning outcomes between a 'cooperative' and 'non-cooperative' class of philological course students $(\mathrm{N}=44$; $\mathrm{M}=4 ; \mathrm{F}=40$; aged 16 and 17). At this point, we should underline that these two 
classes were not subjected to any 'treatment conditions' within a time frame. Namely, both classes had been taught English through the communicative approach, but the teacher of the subsample that is the subject matter of the current investigation ('cooperative class') extensively made use of the cooperative approach in addition, i.e. its theoretical postulates and practical activities. ${ }^{6}$

To achieve sample balancing, firstly we compared their English overall grades and then employed the motivational scale LLOS-IEA (Noels et al., 2000), which displayed good internal consistency $(\alpha=.916)$. Since their grades were quite levelled, and no statistical differences were found in the participants' motivational components (except on the Intrinsic Motivation-Stimulation subscale), we concluded that the two subsamples were quite balanced and that any potential differences may be due to the teaching approach through which they were taught this school subject and not their motivation or proficiency. We also tested students' perceptions of their learning environment via the L2 Learning Context Scale (Grubor, 2012), which also showed good internal consistency $(\alpha=.945)$. The cooperative class evaluated their overall learning environment better $(t(20.11)=5.811 ; p=.000)$, as well as all individual factors (teacher, textbook, rapport, interaction, teaching method, teacher's engagement, class/subject matter content etc, with the level of significance ranging from $p=.000$ to $p=.009$ ).

Accordingly, in this study we focus our attention on the cooperative class, in the first place on the participants' self-reports on the end-of-the-unit LOs pertaining to extra-language subject matter content, since statistically significant differences were found only on this plane in the initial study (Grubor, 2014). ${ }^{7}$ In a word, for the purposes of gathering data, we primarily used a self-reported questionnaire, i.e. an open-cloze questionnaire, to expound on the students' evaluation of the acquired knowledge/skills and their implementation (In this unit: I've learnt ...; Now I can/know how to ...; At home I ...). Furthermore, we used other variables from the initial study as potential contributors to the current results, such as the language of instruction (L2) and students' attitudes to their L2 learning context. Finally, we used qualitative analysis in the current study to identify and explore extra-language features of self-reported evaluation of their LOs due to the significant statistical differences reported in the initial study (cf. Note 7).

Initially, the participants were not informed about the purpose of completing the assigned tasks, with a view to obtaining answers as valid as possible. The students normally completed such tasks in class; hence, they did not find it unusual. Upon completion, however, the purpose of the questionnaire was explained to the students, and they were asked for informed consent. The permission to use the gathered data was given by all the participants.

\subsection{Sample}

The sample of the current study includes the cooperative class from the original study (its subsample), i.e. twenty-four female students at the intermediate language level. The students were in their third year, with five classes of English weekly, 180 classes annually. The teaching approach predominantly employed since their first year was cooperative learning. One of their teacher's principles was to raise 
students' awareness of the need to be independent learners, responsible for their own learning, as well as learning of others, thereby directly putting central CL tenets into practice. Consequently, one of the overall aims of their teacher was to continually develop both teamwork and 'sociopolitical' skills (cf. Grubor, \& Hinić, 2010) through regular, practical implementation of different CL grouping formats and techniques as well as a host of CL classroom activities. This class regularly had different extensive reading assignments (English grade readers, unabridged English novels, Internet articles and the like) and group work presentations (concerning different cultural topics: English lifestyles, customs, music, history, literature etc). Finally, the language of instruction was exclusively English, they talked to their teacher as well as among each other in English, which also referred to extra-class correspondence and conversations, i.e. the students contacted their teacher via email and talked to her informally in English.

In conclusion, the class that participated in this study is by no means a typical class of students learning English in Serbian state schools. These students are accustomed to using English in different settings and for different purposes; thus, they are not average students struggling to convey a simple message in L2.

\section{Results}

Since the initial study showed that both groups ('cooperative' and 'noncooperative') reported similar results in relation to language-related content of their LOs, and that the only differences were found in connection to extra-language content in all of the categories (in favour of the cooperative class), ${ }^{8}$ we will only present the participants' accounts of extra-language learning outcomes herein.

As stated earlier, a self-reported questionnaire, specifically designed for this research, was used to determine the students' evaluation of LOs after a topic-based unit. The main idea behind the questionnaire was to determine, in the first place, the participants' perceptions concerning the knowledge and skills gained in the unit, as well as their implementation in everyday life. We will henceforth present each of the tested 'categories' in turn, with students' exact words given in italics.

\subsection{Acquired knowledge (I've learnt...)}

After performing a detailed content analysis of the students' accounts of LOs, we set out to group the gathered results. The results showed that the participants' perceptions within this category fell into three broad subcategories: (1) endangered species, (2) human/personal involvement/responsibility, and (3) specific types of disasters (pollution, recycling, and 'other').

Particularly, within the category of endangered species, the situation is as follows: all the participants stated at least one item in relation to the issue of endangered species $(100 \%)$. The reason for such an impressive number must be the fact that the unit included different reading, listening and/or speaking activities concerning African gorillas, rhinoceros and other endangered species (koalas, the Bengal tiger etc). However, we believe that the 'teaser' the teacher used, Lonesome George, ${ }^{9}$ as well as the research work which was part of their homework, ${ }^{10}$ added to the situation. 
As for the reported items, the participants stated that they learnt: that people hunt endangered animals just for fur; people needed gorillas' help and gorillas needed people's help to solve their problems; who Lonesome George is/was; some solutions how to save endangered species; about endangered animals and how to protect them; that there are 600 mountain gorillas left, people killed them and sold parts of their bodies as souvenirs to tourists etc.

The next category the reported items fell into represented human/personal responsibility and/or involvement, i.e. the fact that human beings are responsible for many environmental problems and constantly need to take necessary preventive measures. $78 \%$ of the participants reported at least one item in relation to the said category. The reason for such results may be supported by the fact that the textbook activities included the element of human responsibility, either indirectly through some tasks (e.g. the reading comprehension task about African gorillas, which are on the verge of extinction), or directly (e.g. the questionnaire entitled "How environmentally aware are you", problem-solving activities etc).

Some of the reported items within this subcategory were: what we can do and how to help solve many problems on earth, like acid rain, deforestation etc; people are not careful with nuclear waste and most of them don't care about recycling; just how much people did harm to the earth and how they are still doing $i t$; many people and organisations are making efforts to 'fix' what *have been done in the past; the Earth is crying ${ }^{11}$ because people are destroying it; how to save energy; we should recycle rubbish; cities are being destroyed by factories and all other toxic fumes which are released by vehicles; measures which should be taken in order to prevent greater *damages that people *make etc.

Finally, the last broad category was specific types of disasters: a) recycling, b) pollution and c) 'other'. The students stated at least one item in relation to recycling (39\%), pollution (64\%) and other (41\%). The stated examples were: a) about recycling (metal, paper, plastic) and [disposing of] litter; how important recycling is; b) about water and air pollution; [the] ozone layer is damaged and because of that more and more people are getting skin cancer; pollution is everywhere; I need to care more and if I can, raise awareness *about pollution; c) *the cities are spreading very fast (urban sprawl); deforestation, nuclear explosions, acid rain; oil slick etc.

\subsection{Acquired skills (Now I can/know how to...)}

Similarly to the previous category, the results of the main research (Grubor, 2014) showed statistically significant differences in favour of CC with regard to extra-language learning outcomes concerning skills acquired through the unit.

The results of content analysis employed in this study indicated two broad categories: implementation of knowledge (raising awareness, discussing the problems with other people etc) and setting an example (behaving accordingly and/or taking concrete actions towards the protection of the environment).

The first extracted category, implementation of knowledge, is very important given that acquired knowledge does not necessarily lead to certain actions. To put it 
differently, the fact that somebody has knowledge about recycling does not mean that they will do something about it. ${ }^{12} 78 \%$ of the students stated at least one item concerning the said subcategory. The examples were as follows: talk about endangered species and how to protect them; I can talk to people in order to help them realise the problems; tell other people about the things I am now aware of; raise awareness of other people around me by talking about it or spreading it on the Internet, ${ }^{13}$ help the environment by having healthier habits; now I know that I should change my behaviour *about some things and take more care of animals and nature; I know how to prevent pollution because I know its causes.

The second extracted category, setting an example, is even more important than the previous one, in the sense that one of the principles of the cooperative approach is to form active, responsible citizens. Accepting personal and general responsibility, as well as taking concrete actions make these students not only active and responsible citizens (environmentally conscious - thinkers), but also proactive (environmentally proactive - initiators/doers). 64\% of the students stated at least one item within this category, and some of the examples were: take care about the earth by recycling paper, metal, plastic; use a bicycle instead of cars or public transport; save water by turning the tap off when brushing [my] teeth; help animals to survive; now I can teach my friends and parents about the things I've learned, for example, how to help our nature; help different organisations and *asocciations by volunteering; refuse to take plastic bag[s] in supermarkets: ${ }^{14}$ decrease pollution of my environment, for example, I can recycle, save water and electric energy etc.

\subsection{At home I ...}

Besides investigating the students' accounts of the acquired knowledge and skills, we also wanted to determine whether the participants put some of the acquired subject matter content into practice, so we included yet another category: the implementation of the acquired.

As it was the case with the first part of the questionnaire presented above, two main categories were singled out: (1) getting further informed (cf. above: environmentally conscious - thinkers), and (2) taking pro-environmental actions in the future (cf. above: environmentally proactive - initiators/doers). Since the participants' accounts match the already stated items to a great extent, we will sum up the overall results, presenting the most frequently stated answers only.

The first category could be further classified under (a) other endangered species, and (b) what problems the Earth is facing and preventive measures that can be introduced. With regard to (1a) $60 \%$ of the sample stated that they searched for 'endangered species representatives', the reasons that had lead to their near extinction and preventive measures that could be introduced in order to save them, and (1b) how to save energy and water (72\%), how to dispose of litter (60\%) etc. The second category included the same categories as under (1), but this time they stated that they had started implementing the knowledge they acquired through their own research (e.g. they started separating litter and recycling it, saving water and energy by limiting their own use of them, detaining from using plastic bags etc). 
To conclude, based on the participants' accounts of their learning outcomes, the results indicate that not only were they prompted to further investigate the issues covered in class, but they also did concrete actions to implement the acquired.

\section{Discussion}

Bearing in mind the key dimensions of SLOs, stated at the beginning of the paper, we will briefly summarise the main findings of the present study in this section. First of all, based on the results we can state that the concrete instances of self-reported evaluation of LOs reported by our participants can be classified under:

(1) knowledge dimension - since the participants' self-reports pertained to the acquired (extra-language) knowledge and were clustered around (a) endangered species, (b) human/personal involvement/responsibility, (c) specific types of disasters;

(2) capabilities dimension - because the participants' self-reports related to the acquired (extra-language) skills and competencies and were grouped around (a) knowledge application, and (b) setting an example (i.e. behaving accordingly);

(3) application of the acquired - including both the volitional element directly, through two extracted categories (a) getting further informed, (b) taking proenvironmental actions in the present (and possibly future), as well as the affective dimension indirectly (cf. below).

The application-of-the-acquired dimension is conceived of as complex, thus including the previously stated affective element (cf. Introduction) in that the participants' actions speak in favour of their positive attitudes not only to the teaching unit at issue but also to their learning environment, as found in the initial study. More importantly, these participants performed the behaviour in question (i.e. took concrete actions, or applied the acquired knowledge and skills in everyday life), which exemplifies the volitional element, i.e. their determination and resolve (cf. intention in the theory of planned behaviour). The fact that students have knowledge about something ('I know something') and skills required to put their knowledge into practice ('I am able to do it') does not necessarily mean that they will apply it. Knowledge and skills must be followed by volition ('I'm doing it of my own free will'), which is accompanied by positive affect ('I associate positive emotions with it').

Simply put, provided that they are accompanied with positive attitudes and intention to perform 'behaviour' (as specified above), knowledge/knowledge structures (concerning the subject matter content and student awareness of the learnt) and skills/abilities (regarding the existence and awareness of their capabilities) will most likely result in the performance of the behaviour (application of the acquired). To conclude, as stated earlier in this paper, our participants exhibited that they are both environmentally conscious (i.e. thinkers), and environmentally proactive (i.e. initiators/doers).

We should recall at this point the following data concerning the initial study and the sample since they are vital for the findings of the present study. The results of the initial research (Grubor, 2014) show that both the cooperative and non- 
cooperative classes were equally motivated, with no statistical differences in motivational components (intrinsic, extrinsic), nor class attendance (they regularly attended English classes). Therefore, these two variables (motivation and class attendance) cannot account for the results of the research. What is more, the cooperative group reported better study habits, and they evaluated their overall learning environment and its individual components much better. In sum, we assume that the class environment and the teaching approach may have exerted a significant effect on the students' qualitative statements provided in the self-reported questionnaire.

When it comes to research into the implementation of CL in L2 classrooms, unfortunately, studies within EFL context are broadly lacking, so we will call upon one carried out in an ESL and one in EFL context. ${ }^{15}$ Lotan (2008), for example, reports on her investigation into heterogeneous ESL classes consisting of students from different cultural environments and at different proficiency levels, and found the rate of student participation to be a predictor of learning gains. When teachers intervened to ensure equal-status interactions, the gap between high- and lowachievers diminished (ibid.). These findings clearly speak in favour of the employment of the cooperative approach in heterogeneousness classrooms, which are commonplace in Serbian state schools. In addition, since researchers within SLA studies generally agree on the fact that L2 learners must be exposed to linguistically rich environments where they can engage in conversations and negotiate the meaning (e.g. Genesee et al., 2005), we believe that apart from CL, having L2 as the language of instruction must have contributed to such results of our study. ${ }^{16}$ Lotan (2008) also concludes that students must be exposed to linguistic input from their peers as well as from adults, and that the intensive use of language is hence crucial. Apart from the achievement-oriented focus, some authors also emphasise the fact that attitudes and perceptions of students and teachers play a significant role in the successful implementation of CL (Almulla, 2017). In this study, it was found that both teachers and students preferred CL to traditional formats, that this approach brought them both academic as well as social benefits, and that it resulted in enjoyment (ibid.). We can draw a parallel with our findings as well: the cooperative class evaluated the learning environment better, as well as its individual components.

Furthermore, the results of the present study can be interpreted in the light of the main objectives of this teaching approach in language classrooms (cf. Richards, \& Rogers, 2015, p. 245). Namely, one of the objectives is to provide opportunities for students to acquire L2 'naturally' and teachers with the methodology to achieve this goal: the participants perceived extra-language LOs as quite important, they applied what they had learnt; thus, English can be regarded as a vehicle through which they acquire certain content. In addition, CL enables students to develop successful learning and communication strategies: the participants are learning-oriented, have good study habits, focus on the acquired knowledge/skills. CL also enhances learner motivation, reduces stress, generates good rapport: the participants evaluated the learning context much better than the non-cooperative subsample from the initial study. 
Finally, we must reflect on the limitations of our study. First of all, the main limitation is the sample size and its nature, hence the results reflect the perceptions of our sample and further research is needed to expound on the employment of CL. Although many authors state that in language studies girls typically constitute the main part of the sample, having male participants could potentially shed a different light on the subject of the study. As for the sample size, the number of students attending philological courses is typically small (25 students maximum). Nevertheless, having a small sample is commonplace in qualitative studies since researches aim at a more in-depth analysis (cf. Dörnyei, 2011). Secondly, we should also urge caution because the participants are not typical students of English attending Serbian state schools. They attended a course of study for language-gifted students, on the one hand, and on the other, they were exposed to English most of, if not all the time in classes, and/or communication with their teacher out of class. In view of the stated, we suggest that further research should be conducted with students who do not have English as their 'major' and compare the results of the initial and present study with the results obtained from more heterogeneous groups (or in mixed-ability classes). Naturally, we would propose that the cooperative and non-cooperative groups should be balanced in these prospective studies (as in Grubor, 2014). In specific, regarding the variables that can make a significant difference to the results (the level of their English proficiency, motivation to learn English, attitudes to their learning environment etc), so that the results could be scientifically valid, measurable, and thus comparable.

\section{CONCLUSION}

We started off this paper with the focus on contemporary teaching practices, teaching methods/approaches, and learner independence and autonomy as the main precursor to efficacious class. Since 'learning and thinking in the subject matter come about through socially situated negotiations of meaning and active construction of knowledge' (Lotan, 2008, pp. 192-193), the teaching approach that provides both opportunities for social interactions of equal status and an environment conducive to learning is the cooperative approach. We have already stated many advantages based on empirical data, but overall we can conclude that CL promotes social support, psychological health, self-esteem, social skills, continuing motivation, attitudes towards learning, continuous improvement (Johnson, \& Johnson, 2014). Due to numerous advantages, many authors regard student-to-student interaction as the cornerstone of successful teaching and the main precursor of student learning (Lotan, 2008, p. 190). As Johnson and Johnson beautifully put it (Johnson, \& Johnson, 2014, p. 479):

"Every human society has used groups to accomplish its goals and celebrated when the groups were successful. Groups built the pyramids, constructed the Temple of Artemis at Ephesus, and created the Colossus of Rhodes and the hanging gardens of Babylon. [...] Many educators, however, overlook opportunities to use groups to enhance student learning and increase their own success".

In a word, cooperation produces considerable benefits as well as better results to different group members. Apart from team efforts and resultant success, 
interacting with other members brings about the development of both intrapersonal and interpersonal skills, thus members learn more about themselves and others. Finally, being given a personal share of responsibility through individual accountability typically enables students to feel more independent and autonomous, and consequently self-confident. This autonomy and independency seem to have influenced our participants' views on what they have learnt/achieved by the end of a teaching unit. Judging from what they stated, we may assume that the participants regard learning English not as a primary means to learn the language per se, but as a means to learn across-the-curriculum content through English. However, we believe that some other variables might have also contributed to such results: L2 as the language of instruction and positive attitudes to the learning environment, either as variables directly influencing the 'nature' of their accounts of LOs or indirectly through CL. In other words, these variables might have directly facilitated the participants' acquisition of the extra-language subject matter content in that they feel comfortable to acquire a variety of contents through English, or else, the employment of CL might have contributed to students' confidence in their mastery of English and more positive attitudes to the learning environment.

Finally, as we have already implied in this paper, the implementation of CL appears not to be fully embraced in Serbian state schools, taking into account informal comments of students and teachers at any level of education. However, this does not seem to be 'the problem' of our education system only since many authors maintain that the training of teachers is of first-and-foremost importance. Within the UK context, for example, Baines et al. (2008, p. 69) state that 'teachers need to legitimise, support and integrate group working practices into their classrooms and curriculum' and to realise that the social context in their classrooms may promote or inhibit learning. Within the USA context, Lotan (2008, p. 193) argues that a change of focus (from individualistic to interdependent work) requires teachers to comprehend that they need to change their educational practices in 'academically and linguistically heterogeneous classrooms'. Apart from the stated ESL examples, within the EFL context (in Saudi Arabia and Israel in specific), Almulla (2017) and Guri-Rosenblit (2002) assert that the training must come from two directions, i.e. the top-down (coming from educational authorities) and bottom-up (from teachers and students to school management). Accordingly, in future research we will aim at investigating teachers' perceptions and consequently attitudes towards CL and the implementation of this teaching approach in Serbian state schools.

In conclusion, the initial (Grubor, 2014) and the current study have shown that CL does raise awareness of learners, it facilitates and embraces the acquisition of both general knowledge and life skills, in addition to L2. Interestingly, learners are ready to acquire and apply their knowledge in terms of learning English, on the one hand, and 'naturally' acquire the content of different subjects, on the other. However, we should be cautious at this point since some other variables, such as L2 as the language of instruction, have probably contributed to such results as well. With regard to SLOs, the focus on them is frequently included in modern textbooks, although it is questionable whether such tasks (e.g. self-assessment at the end of a unit focusing on the realisation of LOs) are done in class or not (i.e. whether the 
teacher rather 'skips' such tasks). Accordingly, it would be desirable to test how teachers themselves perceive the employment of cooperative learning in EFL classrooms, on the one hand, and whether they attach importance to the significance of SLOs in terms of getting feedback on their teaching, used materials, methods/approaches etc, on the other. As stated above, these issues will be investigated elsewhere.

\section{References}

Almulla, M. (2017). An investigation of Cooperative Learning in a Saudi high school: A case study on teachers' and students' perceptions and classroom practices. (Doctoral dissertation). University of Leicester, Leicester, the United Kingdom.

Baer, J. (2003). Grouping and achievement in cooperative learning. College Teaching, 51 (4), 169-174. https://doi.org/10.1080/87567550309596434

Baines, E., Blatchford, P., \& Kutnick, P. (2008). Pupil grouping for learning: Developing a social pedagogy of the classroom. In R. M. Gillies, A. F. Ashman \& J. Terwel (Eds.), The teacher's role in implementing cooperative learning in the classroom: Computer-supported collaborative learning (Vol. 7, pp. 56-72). New York: Springer.

Brandon, D. P., \& Hollingshead, A. B. (1999). Collaborative learning and computer supported groups. Communications Education, 48, 109-126. https://doi.org/10.1080/03634529909379159

Brecke, R., \& Jensen, J. (2007). Cooperative learning, responsibility, ambiguity, controversy and support in motivating students. Insight: A Journal of Scholarly Teaching, 2(1), 57-63.

Cohen, E. G. (1994). Designing groupwork: Strategies for the heterogeneous classroom. $2^{\text {nd }}$ edition. New York: Teachers College Press.

Dörnyei, Z. (2011). Research methods in applied linguistics. Oxford: Oxford University Press.

Duxbury, J. G., \& Ling, L. T. (2010). The effects of cooperative learning on foreign language anxiety: A comparative study of Taiwanese and American universities. International Journal of Instruction, 3(1), 3-18.

Fathi-Ashtiani, A., Salimi, S-H., Aybi, M., \& Mohebbi, H-A. (2007). A comparison of the cooperative learning model and traditional learning model on academic achievement. Journal of Applied Sciences, 7 (1), 137-140.

Gass, S., \& Selinker, L. (2008). Second language acquisition: An introductory course. $3^{\text {rd }}$ edition. New York/London: Routledge.

Genesee, F., Lindholm-Leary, K., Saunders, W., \& Christian, D. (2005). English language learners in U.S. schools: An overview of research findings. Journal of Education for Students Placed at Risk, 10, 363-385.

Grubor, J. (2014). Beyond teaching English: Cooperative learning in class. In Z. Paunović (Ed.), ELLSEE Proceedings (pp. 289-298). Belgrade: Faculty of Philology, University of Belgrade.

Grubor, J. (2012). Stavovi prema učenju engleskog kao stranog jezika i njihov uticaj na postignuće. (Doktorska disertacija). Filološki fakultet, Beograd, Srbija. 
Grubor, J., \& Hinić, D. (2010). Extroversion: A factor influencing enjoyment in role play in EFL students? The New Educational Review, 21 (2): 293-305.

Guri-Rosenblit, S. (2002). A top down strategy to enhance information technologies into Israeli higher education. International Review of Research in Open and Distance Education, $2(2), 1-16$.

Hertz-Lazarowitz, R., \& Miller, N. (eds). (1992). Interaction in cooperative groups: The theoretical anatomy of group learning. Cambridge: Cambridge University Press.

Hornby, G. (2009). The effectiveness of cooperative learning with trainee teachers. Journal of Education for Teaching: International Research and Pedagogy, 35(2), 161-168.

Huber, A. A. (Hrsg.) (2004). Kooperatives lernen - kein problem. Effektive methoden der partner- und gruppenarbeit. Stuttgart: Klett, 4-15.

Jacobs, G. M., \& Renandya, W. A. (2019). Student centered cooperative learning: Linking concepts in education to promote student learning. Singapore: Springer Nature Singapore Pte Ltd.

Jones, N., \& Saville, N. (2016). Learning oriented assessment: A systemic approach, studies in language testing. Volume 45. Cambridge: Cambridge University Press.

Jones, N., \& Saville, N. (2014). Learning-oriented assessment. Cambridge: Cambridge English discussion paper.

Johnson, D. W., \& Johnson, F. P. (2014). Joining together group theory and group skills. $11^{\text {th }}$ edition. Harlow: Pearson.

Johnson, D. W., \& Johnson, R. T. (2013). Cooperative learning and non-academic outcomes of schooling: The other side of the report card. In J. E. Pedersen \& A. D. Digby (Eds.), Secondary Schools and Cooperative Learning: Theories, Models, and Strategies (pp. 81152). New York: Routledge.

Johnson, D. W., \& Johnson, R. T. (1989). Cooperation and competition: Theory and research. Edina, MN: Interaction Book Company.

Johnson, D. W., \& Johnson, R. T. (1974). Instructional goal structure: Cooperative, competitive, or individualistic. Review of Educational Research, 44, 213-240. http://doi.org/10.3102/00346543044002213

Johnson, D. W, Johnson, R. T. \& Smith, K. A. (2007). The state of cooperative learning in postsecondary and professional settings. Educational Psychology Review, 19 (1), 15-29. http://dx.doi.org/10.1007/s10648-006-9038-8

Johnson, D. W., Johnson, R. T., \& Smith, K. A. (1998). Cooperative learning returns to college: What evidence is there that it works? Change, 30 (4), 26-35. http://doi.org/10.1080/00091389809602629

Lotan, R. A. (2008). Developing language and mastering content in heterogeneous classrooms. In R. M. Gillies, A. F. Ashman \& J. Terwel (Eds.), The teacher's role in implementing cooperative learning in the classroom: Computer-supported collaborative learning (Vol. 7, pp. 184-200). New York: Springer.

Marr, M. B. (1997). Cooperative learning: A brief review. Reading and Writing Quarterly: Overcoming Learning Difficulties, $13 \quad$ (1), 7-20. https://psycnet.apa.org/doi/10.1080/1057356970130102 
Noels, K. A., Pelletier, L. G., Clément, R., \& Vallerand, R. J. (2000). Why are you learning a second language? Motivational orientations and self-determination theory. Language Learning, 50(1), 57-85. https://doi.org/10.1111/0023-8333.00111

O'Donnell, A. M. (2006). The role of peers and group learning. In P. A. Alexander \& P. H. Winne (Eds), Handbook of Educational Psychology ( $2^{\text {nd }}$ Edn, pp. 781-802). New Jersey: Lawrence Erlbaum Associates, Inc. Publishers.

Olsen, R., \& Kagan, S. (1992). About cooperative learning. In C. Kessler (Ed.), Cooperative language learning: A teacher's resource book (pp. 1-30). New York: Prentice Hall.

Pritchard, A., \& Woollard, J. (2010). Psychology for the classroom: Constructivism and social learning. Abingdon: Routledge.

Purpura, J., \& Turner, C. (2014). "A learning-oriented assessment approach to understanding the complexities of classroom-based language assessment". Paper presented at the Roundtable on Learning-oriented Assessment in Language Classrooms and Large-scale Contexts. Teachers College, Columbia University, New York.

Richards, J. C., \& Rodgers, T. S. (2015). Approaches and methods in language teaching. $3^{\text {rd }}$ edition. Cambridge: Cambridge University Press.

Roseth, C. J, Johnson, D. W., \& Johnson, R. T. (2008). Promoting early adolescents' achievement and peer relationships: The effects of cooperative, competitive, and individualistic goal structures. Psychological Bulletin, 134 (2), 223-246. https://doi.org/10.1037/0033-2909.134.2.223

Sharan, Y. (2014). Learning to cooperate for cooperative learning. Anales De Psicologia, 30 (3), 802-807. http://dx.doi.org/10.6018/analesps.30.3.201211

Slavin, R. E. (2014). Cooperative learning and academic achievement: Why does groupwork work? Anales De Psicologia, 30 (3), 785-791. http://doi.org/10.6018/analesps.30.3.201201

Slavin, R. E. (1995). Cooperative Learning: Theory, research and practice. $2^{\text {nd }}$ edition. Boston, MA: Allyn \& Bacon.

Tarim, K. (2009): The effects of cooperative learning on preschoolers' mathematics problemsolving. Educational Studies in Mathematics, 72(3): 325-340. https://doi.org/10.1080/10409289.2016.1116343

Van Wyk, M. (2012). The effects of the STAD-cooperative learning method on student achievement, attitude and motivation in economics education. Journal of Social Sciences, 33(2): 261-270. https://doi.org/10.1080/09718923.2012.11893104

Watson, S. B. (1991). Cooperative learning and group educational modules: Effects on cognitive achievement oh high school biology students. Journal of Research in Science Teaching, 27, 671-683. https://doi.org/10.1002/tea.3660280205

Wolff, D. (2007). Lernerautonomie und selbst gesteurtes fremdsprachliches lernen: Überblick. In K. R. Bausch, H. Christ und H. J. Krumm (Hrsg.), Handbuch Fremdsprachenunterricht (5. Auflage, Seiten 321-326). Tübingen: Francke.

Zhang, Y. (2010). Cooperative language learning and foreign language learning and teaching. Journal of Language Teaching and Research, 1(1), 81-83. https://doi.org/10.4304/jltr.1.1.81-83 
Primljeno 11. jula 2020,

nakon revizije,

prihvaćeno za publikovanje 25. septembra 2020.

Elektronska verzija objavljena 1. oktobra 2020.

Jelena Grubor (Hinić) zaposlena je na Studijskom programu Engleski jezik $i$ književnost, na Državnom univerzitetu u Novom Pazaru. Okosnicu njenog naučnoistraživačkog rada čine interdisciplinarna istraživanja prevashodno iz oblasti primenjene lingvistike (usvajanja stranog jezika, lingvistike obrazovanja i metodike nastave engleskog jezika) i sociolingvistike (poddisciplina: jezik i rod, varijeteti engleskog jezika).

\section{VIŠE OD UČENJA ENGLESKOG JEZIKA: KAKO UČENICI OPISUJU ISHODE UČENJA U KOOPERATIVNOJ UČIONICI}

Budući da ishodi učenja (IU) formulisani od strane učenika zauzimaju glavnu ulogu u savremenoj nastavi, i da istraživanja ukazuju na mnoge prednosti kooperativnog učenja, glavni cilj ovog rada je da se ispita kako učenici percipiraju IU, kako bi se odredile njihove ključne dimenzije. Uzorak čine 24 učenice trećeg razreda filološkog smera. Samoprocenu stečenog znanja i veština, i njihove primene analizirali smo tehnikom analize sadržaja. Rezultati ukazuju na to da IU čine sledeće dimenzije: (1) znanja, (2) sposobnosti, i (3) primena usvojenog (podstaknuta voljom i afektom). Osnovni zaključak je da ispitanice ne posmatraju učenje jezika isključivo kao sredstvo za učenje jezika per se, već kao sredstvo putem koga usvajaju različite sadržaje na engleskom jeziku. Varijable koje su potencijalno dodatno doprinele ovakvim rezultatima jesu upotreba engleskog kao jezika učionice i pozitivni stavovi prema nastavnom okruženju.

Ključne reči: engleski kao strani jezik (ESJ), ishodi učenja (IU), kooperativno učenje (KU).

${ }^{1}$ For the positive effect of CL among heterogeneous peers in post-task situations (after the 'treatment'), cf. meta-analysis in Johnson, \& Jonson (1995).

${ }^{2}$ For a recent, insightful and in-depth analysis of learner centeredness, cf. Jacobs, \& Renandya (2019).

${ }^{3}$ For concrete ideas on how to implement CL in schools/classes, cf. Johnson, \& Johnson (2014), Sharan (2014).

${ }^{4}$ For a unified theory of cooperative learning effect on achievement, taking into account the motivational, social cohesion, developmental and cognitive elaboration perspectives, $\mathrm{cf}$. Slavin (2014).

${ }^{5}$ We will call upon the results of the initial study in the Methodology section.

${ }^{6} \mathrm{We}$ are drawing the reader's attention to the fact that CL is widely regarded as an approach that promotes communicative interaction and is thus viewed as an extension of the principles of Communicative Language Teaching (CLT).

7 The significant statistical differences in the initial study were as follows: acquired knowledge: $t(43)=8.714 ; \quad p=.000, \quad$ acquired skills: $t(35.47)=5.752 ; \quad p=.000$, implementation of the skills/knowledge: $t(43)=4.034 ; p=.000)$.

${ }^{8}$ Cf. Note 7. 
${ }^{9}$ The 'teaser' in the form of 'Do you know who Lonesome George is?' was introduced to arouse the students' interest in the topic (cf. Pinta Island giant tortoise, widely known as Lonesome George, which died in 2012). Since the students were not familiar with the name, they got interested in it and checked it at home (on the Internet).

${ }^{10}$ The students had, among other things, a task to find and consequently present within their groups their own example of an endangered species.

${ }^{11}$ The subtitle of one of the texts.

${ }^{12}$ Psychological research into attitudes, for example, shows that intention to perform specific behaviour is its immediate antecedent (cf. the theory of planned behaviour), which has been confirmed in SLA research as well (cf. Grubor, 2012).

13 These items may be regarded to belong to the next subcategory as well (setting an example).

${ }^{14}$ At the time of research, there was still no ban on single-use plastic bags in Serbia, which was introduced in 2019.

${ }^{15}$ For the difference between EFL (English as a foreign language) and ESL (English as a second language), cf. Gass, \& Selinker (2008, p. 7).

${ }^{16}$ Better evaluation of the learning environment, significantly more extra-language LOs etc. 